\title{
Nonlinear Vibration Analysis of Composite Plates on Elastic Foundations in Thermal Environments
}

\author{
İhsan Küçükrendeci \\ Sakarya Üniversitesi, Teknoloji Fakültesi, Makine Mühendisliği Bölümü, Sakarya. \\ e-posta:ikucukrendeci@sakarya.edu.tr
}

\begin{tabular}{|c|c|}
\hline Keywords & bstract \\
\hline $\begin{array}{l}\text { Nonlinear vibration; } \\
\text { Composite plates; } \\
\text { Elastic foundation; } \\
\text { Temperature- } \\
\text { dependent material } \\
\text { properties; Finite } \\
\text { element method }\end{array}$ & $\begin{array}{l}\text { Nonlinear vibrations of composite plates on an elastic foundation in thermal environments are } \\
\text { presented in this study. Graphite/epoxy is selected as the plate material. The properties of composite } \\
\text { material are assumed to be temperature-dependent. Nonlinear free vibrations of laminated composite } \\
\text { plates are investigated in the fully clamped boundary conditions. The classical finite element method is } \\
\text { used and a specially prepared computer code is written in the Matlab software. Vibrations of the spring } \\
\text { supported laminated composite plate are directly influenced by the boundary conditions and } \\
\text { dimensions of plate.In this study, generated graphical values reveal that foundation stiffness and } \\
\text { temperature have significant effects on the linear and nonlinear frequencies of composite plates. }\end{array}$ \\
\hline
\end{tabular}

\section{Termal Ortamda Elastik Tabandaki Kompozit Plakaların Doğrusal Olmayan Titreşim Analizi}

\begin{abstract}
Anahtar kelimeler
Doğrusal olmayan titreşim; Kompozit plaka; Elastik taban; Sıcaklık-malzeme özelliklerine bağlı;Sonlu elemanlar metodu

Bu çalışmada termal ortamda elastik tabandaki bir kompozit plakalarındoğrusal olmayan titreşimleri sunulmaktadır. Grafit/epoksi plaka malzemesi olarak seçilmiştir. Kompozit malzeme özellikleri sıcaklık bağımlı olduğu varsayılmaktadır. Lamine kompozit plakalar doğrusal olmayan serbest titreşimleri tam ankastre sınır koşullarında incelenmiştir. Klasik sonlu elemanlar yöntemi kullanılmıştır ve özel olarak hazırlanmış bilgisayar kodu Matlab yazılımıyla hazırlanmıştır.Lamine Kompozit plakaları destekleyen yayların titreşimleri direk olarak sınır koşulları ve plaka boyutlarıyla etkilenmektedir. Bu çalışmada oluşturulan grafik değerlerden,tabandaki sertlik ve sıcaklı̆ın kompozit plakaların doğrusal ve doğrusal olmayan frekanslarına önemli ölçüde etkilerinin olduğu görülmektedir.
\end{abstract}

\section{Özet}

(c) Afyon Kocatepe Üniversitesi

\section{Introduction}

Due to their outstanding properties, sandwich-type constructions are great role in the construction of space vehicles and transportation systems (Wang and Shen 2011). With the development of technology, it is possible to apply composite plates in high-temperatures. Predicting of the thermoelastic response of composite plates is necessary for the development of efficient models (Zhenet al. 2010).
Many studies have been presented on the linear and nonlinear free vibration analyzes of composite plates. Thermal affects and elastic foundations are less in these studies. Among those; Wanga and Shen (2013) investigated nonlinear dynamic response of sandwich plates with FGM face sheets resting on elastic foundations in thermal environments.Zenkour and Sobhy (2010) studied thermal buckling of various types of sandwich plates.Shen and Zhu (2012) investigated postbuckling of sandwich plates with nanotubereinforced composite face sheets resting on elastic 
foundations. Sofiyev and Kuruoglu(2013) studied the non-linear buckling of the truncated conical shell made of functionally graded materials (FGMs) surrounded by an elastic medium. Li and Lin (2012) presented thermal postbuckling analysis for sheardeformable anisotropic laminated cylindrical shell of finite length. Xu et al.(2013) investigated the nonlinear bending behavior of a bilayer rectangular graphene sheet subjected to a transverse uniform load in thermal environments. Shen (2011) analyzed postbuckling, nonlinear bending and nonlinear vibration analysis of thin film resting on elastic foundation in thermal environments. Zenkour et al.(2013) investigated the bending response of an orthotropic rectangular plate resting on two-parameter elastic foundations under thermomechanical loadings. Zhen et al.(2010) proposed a new efficient global-local higher-order model for the thermoelastic analysis of laminated composite and sandwich plates. Moore et al.(2013) studied thermal response and stability characteristics of bistable composite laminates by considering temperature dependent material properties and resin layers.

In this study, nonlinear vibration analysis of composite plates on elastic foundations in thermal environments is studied. Graphite/epoxy is selected as a plate material. The properties of composite material are assumed to be temperature-dependent. The numerical results showed that the linear and nonlinear vibration characteristics of composite plates on elastic foundations have varied depending on conditions of thermal environment. The classical finite element method is used in the analysis. Also, plate dimensions and boundary conditions have affects on the vibrations of composite plates.

\section{Finite Element Method}

A rectangular element, which is under the effect of bending vibrations, is shown at Fig. 1.The element mass matrix written according to Fig. 1 is shown in Equation 1. Further detail information has been presented by (Petyt 1990).

$$
[\mathrm{M}]_{\mathrm{e}}=\frac{\rho \mathrm{hab}}{6300}\left[\begin{array}{cc}
\mathrm{m}_{11} & \mathrm{~m}_{21}^{T} \\
\mathrm{~m}_{21} & \mathrm{~m}_{22}
\end{array}\right]
$$

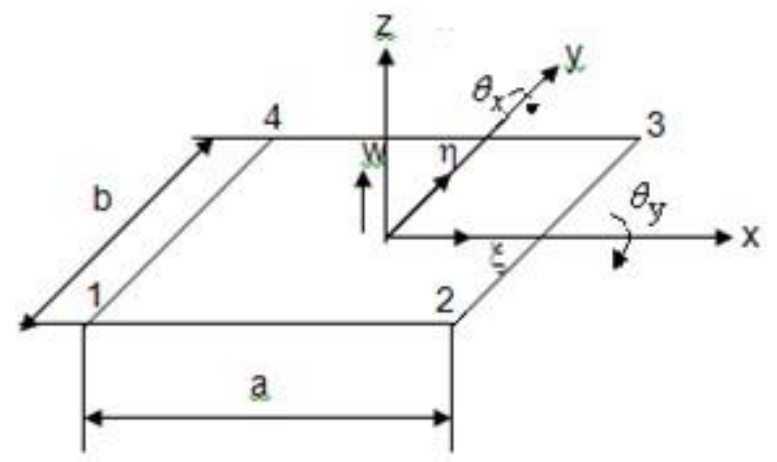

Figure 1. Geometry of a rectangular plate model

$[\mathrm{K}]_{\mathrm{e}} \mathrm{is}$ element stiffness matrix (Morgüland Küçükrendeci2008).

$[\mathrm{K}]_{e N L}=\left[\begin{array}{llll}{[\mathrm{K} *]_{11}} & & & \text { sym. } \\ {[\mathrm{K} *]_{21}} & {[\mathrm{~K} *]_{22}} & & \\ {[\mathrm{~K} *]_{31}} & {[\mathrm{~K} *]_{32}} & {[\mathrm{~K} *]_{33}} & \\ {[\mathrm{~K} *]_{41}} & {[\mathrm{~K} *]_{42}} & {[\mathrm{~K} *]_{43}} & {[\mathrm{~K} *]_{44}}\end{array}\right]$

The geometrical nonlinear strain energy for the highly displaced systems can be given as

$\mathrm{U}_{\mathrm{NL}}=\frac{1}{2} \int_{V}\{\psi\}^{T}\left[\sigma_{0}\right]\{\psi\} d V(3)$

where the matrix $\left[\sigma_{0}\right]$ is axial stresses of the element. $\{\psi\}$ is the nonlinear displacement in the $z$ direction and $\mathrm{V}$ is the volume. The terms of the matrix $\left[\sigma_{0}\right]$ are

$\left\{\sigma_{0}\right\}=[D]\{\{\varepsilon\}-\{\alpha\} \Delta T\}$

$\{\varepsilon\}=\left\{\begin{array}{l}\varepsilon_{x} \\ \varepsilon_{y}\end{array}\right\},\{\alpha\}=\left\{\begin{array}{l}\alpha_{1} \\ \alpha_{2}\end{array}\right\}, \Delta \mathrm{T}=\mathrm{T}_{2}-\mathrm{T}_{1}$

[D] matrix was defined in Morgüland Küçükrendeci (2008). $\alpha$ is thermal expansion coefficient and $\Delta T$ is temperature change. Where $\{\varepsilon\}$ is the axial displacement. $\left[\sigma_{0}\right]$ and $\{\psi\}$ are defined as

$\left[\sigma_{0}\right]=\left[\begin{array}{cc}\sigma_{x} & \tau_{x y} \\ \tau_{x y} & \sigma_{y}\end{array}\right]$

and

$\{\psi\}=\left[\begin{array}{l}\frac{\partial w}{\partial x} \\ \frac{\partial w}{\partial y}\end{array}\right]$ 
Equation (5) can be re-defined using the thickness of the plate element.

$\mathrm{U}_{\mathrm{NL}}=\frac{1}{2} \int_{A} h\{\psi\}^{T}\left[\sigma_{0}\right]\{\psi\} d A$

Substituting Eq. (1) in Eq. (7) gives

$\mathrm{U}_{\mathrm{eNL}}=\frac{1}{2}\left\{\mathrm{w}_{*}\right\}^{\top}[\mathrm{K}]_{\mathrm{eNL}}\left\{\mathrm{w}_{*}\right\}$

Where $\left\{w_{*}\right\}$ is the nonlinear displacement vector. $[K]_{e N L}$ is nonlinear stiffness matrix of the element.

The nonlinear stiffness matrix of the element obtained using Eq. (8). This matrix is in the form of $3 \times 3$ square sub-matrix and shown in Eq. (9),

$[\mathrm{K}]_{e N \mathrm{~L}}=\left[\begin{array}{llll}{[\mathrm{K} *]_{11}} & & & \text { sym. } \\ {[\mathrm{K} *]_{21}} & {[\mathrm{~K} *]_{22}} & & \\ {[\mathrm{~K} *]_{31}} & {[\mathrm{~K} *]_{32}} & {\left[\mathrm{~K}_{*}\right]_{33}} & \\ {[\mathrm{~K} *]_{41}} & {[\mathrm{~K} *]_{42}} & {[\mathrm{~K} *]_{43}} & {[\mathrm{~K} *]_{44}}\end{array}\right]$ (9)

\section{Nonlinear Vibration Analysis}

Eq. (10) is used for free vibration analysis of the laminated composite plates.

$$
[\mathrm{M}]\{\ddot{\mathrm{u}}\}+[\mathrm{K}]\{\mathrm{u}\}=\{0\}
$$

In Eq. (10), [M] and [K] are system mass matrix and system stiffness matrix. System matrix is obtained by combining of elementary matrices.

Natural frequencies " $\omega$ " and modes of vibration is determined in linear free vibration analysis by solving the eigenvector of structure.

$\left([\mathrm{K}]-\omega^{2}[\mathrm{M}]\right)\{\Phi\}=\{0\}$

where $\{\Phi\}$ is eigenvector.

$\left[\mathrm{K}^{\mathrm{S}}\right]$ is spring matrix. $\left[\mathrm{K}^{\mathrm{S}}\right]$ matrix is added to the $[\mathrm{K}]$ matrix and the Eq. (12) is obtained.

$\left[\left([\mathrm{K}]+\left[\mathrm{K}^{\mathrm{s}}\right]\right)-\omega^{2}[\mathrm{M}]\right]\{\Phi\}=\{0\}$

Eq. (14) is used for the analysis of linear free vibrations.

The nonlinear free vibration analysis is carried by solving equations of geometrical nonlinearity system. An iteration steps are used for each deformation stage in the solution. Nonlinear free vibration analysis requires a series of operations
(Karadağ and Morgül 1992). The nonlinear element stiffness matrix $[\mathrm{K}]_{\mathrm{eNL}}$ is given in Eq. (13). $[K]_{\mathrm{NL}}$ matrix can be written by the combination of nonlinear elementary stiffness matrices.

$\left[\left([\mathrm{K}]+[\mathrm{K}]_{\mathrm{NL}}+\left[\mathrm{K}^{\mathrm{S}}\right]\right)-\omega_{N L}^{2}[\mathrm{M}]\right]\left\{\Phi_{\mathrm{NL}}\right\}=\{0\}$

Nonlinear natural frequencies $\left(\omega_{N L}\right)$ and nonlinear unitvector $\left\{\Phi_{\mathrm{NL}}\right\}$ are calculated by solution of Eq. (13). The damping factor was not taken into accountin the analyzes.

\section{Physical Properties of Composite Plates}

In this study, flat composite laminated plates are used. The plate models are in the form of rectangular. The dimensions of all the plate models are selected $a \mathrm{a} a / b=1$ and $a / b=2$. Composite plate is formed by five laminates of overlapping lined up. Laminates are lined up symmetrically as $(\theta,-\theta, \theta$, $-\theta, \theta) . \theta$ is orientation angle of laminates. Two different orientation angle are selected in the analyzes. These angles are $30^{\circ}$ and $45^{\circ}$. For example, $\theta=30^{\circ}$; angles of five laminated plates are $30^{\circ},-30^{\circ}, 30^{\circ},-30^{\circ}, 30^{\circ}$, respectively. Where, the laminates are fiber fabrics and its material is selected as a graphite/epoxy in this study. Temperature dependent mechanical properties of graphite/epoxy are shown in Table 1 . The fiber fabrics are placed one on the top with different orientation angles. So that symmetrically laminated composite plate is obtained. The thickness of the fiber fabric layers is chosen as $0.2 \mathrm{~mm}$. So the total thickness of composite plates is $\mathrm{h}=1 \mathrm{~mm}$.

\begin{tabular}{lcccc}
\hline & \multicolumn{4}{c}{ Temperature $\left({ }^{\circ} \mathrm{C}\right)$} \\
\cline { 2 - 5 } & 20 & 200 & 260 & 600 \\
\hline $\mathrm{E}_{1}(\mathrm{GPa})$ & 141 & 141 & 141 & 141 \\
\hline $\mathrm{E}_{2}(\mathrm{GPa})$ & 13.1 & 10.3 & 0.138 & 0.0069 \\
\hline $\mathrm{G}_{12}(\mathrm{GPa})$ & 9.31 & 7.45 & 0.069 & 0.0034 \\
\hline $\mathrm{v}_{12}$ & 0.28 & 0.28 & 0.28 & 0.28 \\
\hline $\mathrm{v}_{21}$ & 0.026 & 0.020 & 0,00027 & 0,000013 \\
\hline$\alpha_{1}\left(10^{-6} /{ }^{\circ} \mathrm{C}\right)$ & 0.0018 & 0.054 & 0.054 & 0.054 \\
\hline$\alpha_{2}\left(10^{-6} /{ }^{\circ} \mathrm{C}\right)$ & 21.6 & 37.8 & 37.8 & 37.8 \\
\hline
\end{tabular}

Table 1. Temperature dependent mechanical properties of graphite/epoxy (Singha et al. 2001)

A fully clamped boundary condition is selected for composite plate models. The spring supports and 
the plate dimensions are shown in Fig. 2. Selected spring stiffness values are $k_{1}=1000 \mathrm{~N} / \mathrm{m}$ and $k_{2}=0$.

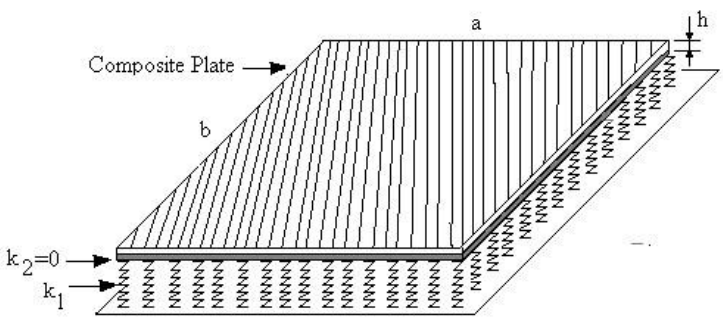

Figure 2.Model of spring supported laminated composite plate

\section{Numerical Analysis}

In Morgüland Küçükrendeci (2008), the boundary conditions of composite plates were also selected as fully clamped. The parameters of natural frequency of the undamped free vibration were calculated according to the Eq. (16). In Hanand Petyt (1996) andChowet al.(1992)frequency parameters were found for composite plates in similar conditions but they have used different analyzes methods. Frequency parameters of Morgüland Küçükrendeci (2008) were compared with Hanand Petyt (1996) andChowet al.(1992) for the first 14 vibration modes. Similar results were obtained. [K] and [M] matrices of Morgüland Küçükrendeci (2008) were selected for the next stages of this study.

$\mathrm{D}_{0}=\mathrm{E}_{1} \mathrm{~h}^{3} / 12\left(1-\mathrm{v}_{12} \mathrm{v}_{21}\right)$

$\lambda=\rho h \omega^{4} a^{4} / D_{0}$

Linear and nonlinear frequency parameters are calculated using Eq. (14). In calculations are considered physical properties of composite plates given in section 4.The classical finite element method is used in the analyzes. New matrix of $[\mathrm{K}]_{\mathrm{e}}$ and $[K]_{\text {eNL }}$ are calculated using Eq. (4). The effect of temperature is also taken into account in these calculations. The results of the frequency values for the first 18 mode are graphically presented in Fig. 3-10.In analyzes the geometrical nonlinearity is used. In calculations is used a specially prepared computer codes in the Matlab software.

In Fig. 3, the first 15 mode frequencies are close to each other at all temperatures. At $20^{\circ} \mathrm{C}$ and $200^{\circ} \mathrm{C}$, frequency values are close to each other in all modes. At $240^{\circ} \mathrm{C}$ and $600^{\circ} \mathrm{C}$, frequency values are very close to each other in all modes.

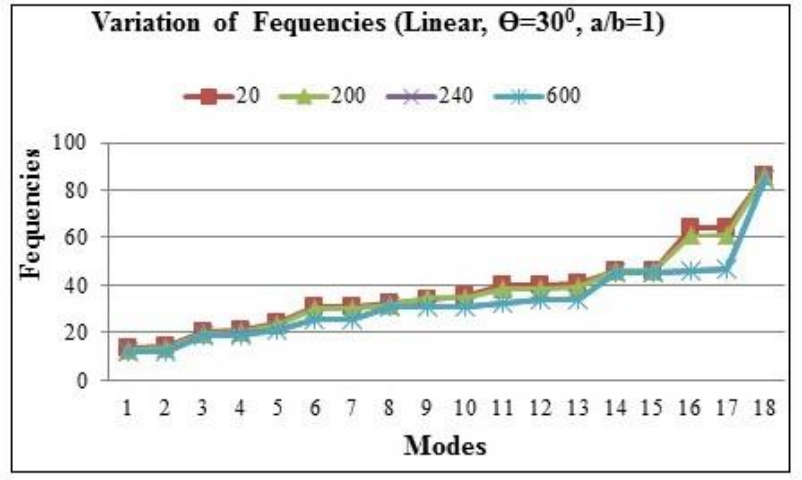

Figure 3.Linear frequency parameters of laminated composite plate model supported by springs at fully clamped boundary conditions $\left(\theta=30^{\circ}\right.$, graphite/epoxy, $\mathrm{a} / \mathrm{b}=1$, temperatures; $20^{\circ} \mathrm{C}, 200^{\circ} \mathrm{C}, 240^{\circ} \mathrm{C}, 600^{\circ} \mathrm{C}$ )

In Fig. 4 , at $200^{\circ} \mathrm{C}$ and $240^{\circ} \mathrm{C}$ temperatures, frequency values are similar in all modes. Low frequencies are observed at the temperature of $600^{\circ} \mathrm{C}$. At $20^{\circ} \mathrm{C}$ temperature, a rise in frequency is seen after the tenth mode. In Fig. 5 , at $20^{\circ} \mathrm{C}, 200^{\circ} \mathrm{C}$ and $600^{\circ} \mathrm{C}$ temperatures, frequency values are similar in all modes. At temperature of $240^{\circ} \mathrm{C}$, frequency values are getting lower after the tenth mode. In Fig. 6, at $600^{\circ} \mathrm{C}$, frequency values are higher in all modes. At temperatures of $200^{\circ} \mathrm{C}$ and $240^{\circ} \mathrm{C}$, frequencies are close to each other in all modes. In $20^{\circ} \mathrm{C}$ temperature, frequency values are variable.

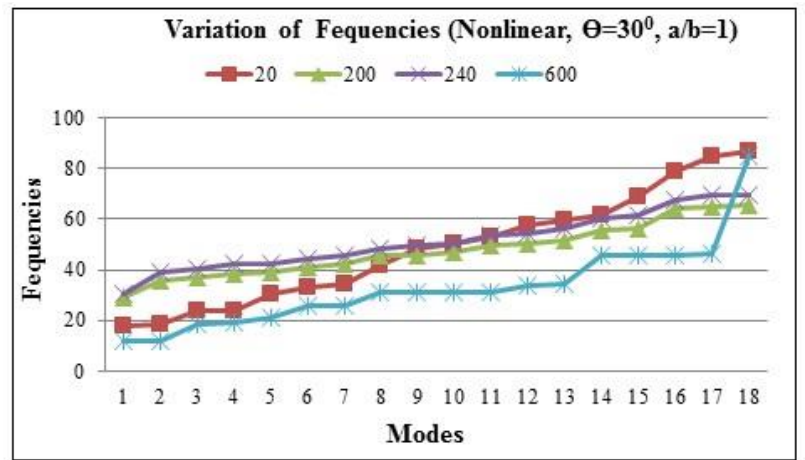

Figure 4. Nonlinear frequency parameters of laminated composite plate model supported by springs at fully clamped boundary conditions $\left(\theta=30^{\circ}\right.$, graphite/epoxy, $\mathrm{a} / \mathrm{b}=1$, temperatures; $20^{\circ} \mathrm{C}, 200^{\circ} \mathrm{C}, 240^{\circ} \mathrm{C}, 600^{\circ} \mathrm{C}$ ) 


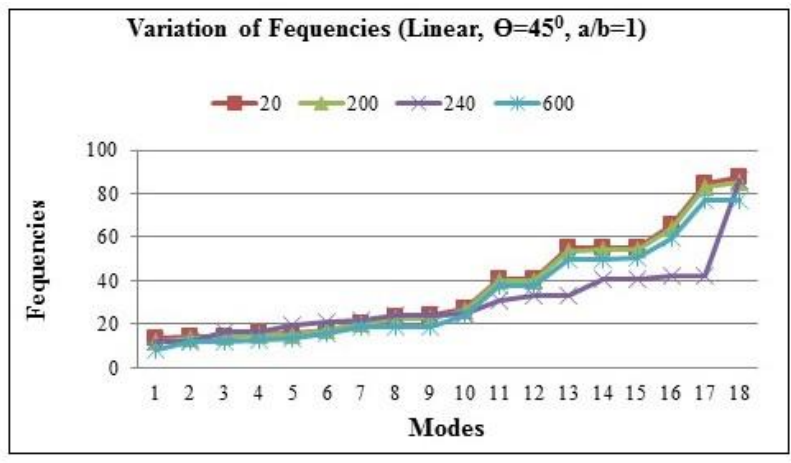

Figure 5. Linear frequency parameters of laminated composite plate model supported by springs at fully clamped boundary conditions $\left(\theta=45^{\circ}\right.$, graphite/epoxy, $\mathrm{a} / \mathrm{b}=1$, temperatures; $20^{\circ} \mathrm{C}, 200^{\circ} \mathrm{C}, 240^{\circ} \mathrm{C}, 600^{\circ} \mathrm{C}$ )

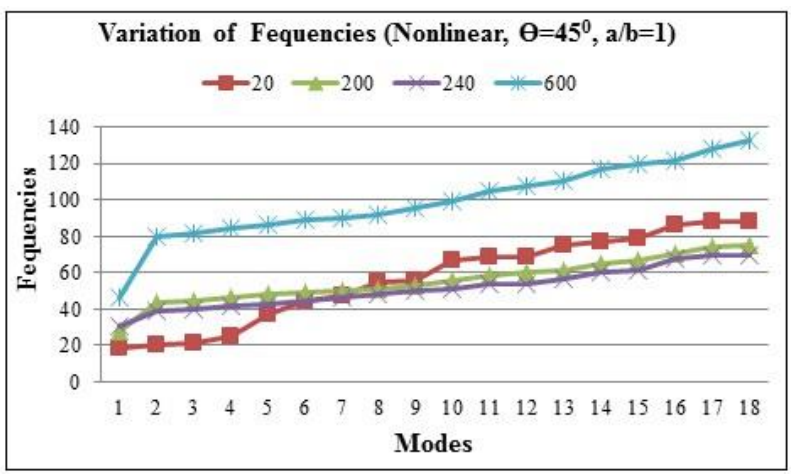

Figure 6. Nonlinear frequency parameters of laminated composite plate model supported by springs at fully clamped boundary conditions $\left(\theta=45^{\circ}\right.$, graphite/epoxy, $\mathrm{a} / \mathrm{b}=1$, temperatures; $20^{\circ} \mathrm{C}, 200^{\circ} \mathrm{C}, 240^{\circ} \mathrm{C}, 600^{\circ} \mathrm{C}$ )

In Fig. 7, at $20^{\circ} \mathrm{C}, 200^{\circ} \mathrm{C}, 240^{\circ} \mathrm{C}$ and $600^{\circ} \mathrm{C}$ temperatures, frequency values are similar in the first twelve modes. So it can be said that there is no significant effect of temperature for these modes.

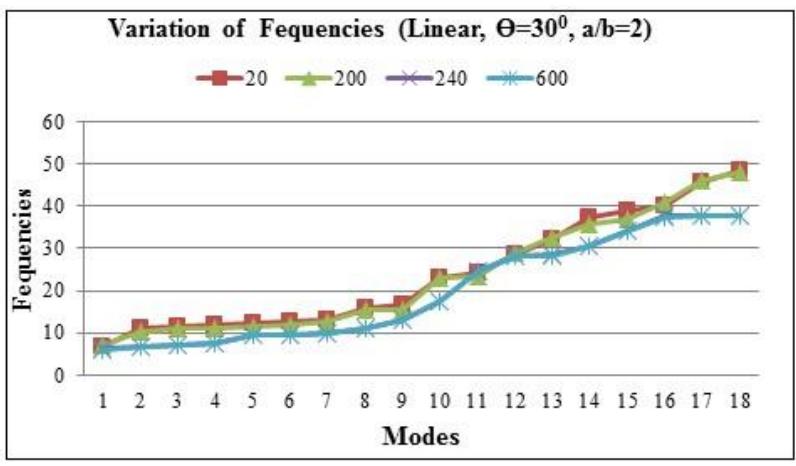

Figure 7. Linear frequency parameters of laminated composite plate model supported by springs at fully clamped boundary conditions $\left(\theta=30^{\circ}\right.$, graphite/epoxy, $\mathrm{a} / \mathrm{b}=2$, temperatures; $20^{\circ} \mathrm{C}, 200^{\circ} \mathrm{C}, 240^{\circ} \mathrm{C}, 600^{\circ} \mathrm{C}$ )

In Fig. 8 , at temperature of $600^{\circ} \mathrm{C}$, frequency values are high in all modes. At temperatures of $200^{\circ} \mathrm{C}$ and $240^{\circ} \mathrm{C}$, frequencies are close to each other in all modes. At $20^{\circ} \mathrm{C}, 200^{\circ} \mathrm{C}$ and $240^{\circ} \mathrm{C}$ temperature, after the tenth mode, frequency values are close to each other.

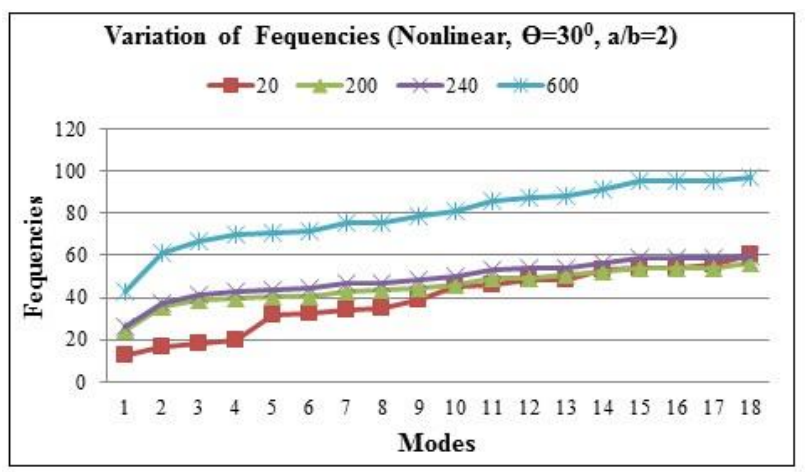

Figure 8. Nonlinear frequency parameters of laminated composite plate model supported by springs at fully clamped boundary conditions $\left(\theta=30^{\circ}\right.$, graphite/epoxy, $\mathrm{a} / \mathrm{b}=2$, temperatures; $20^{\circ} \mathrm{C}, 200^{\circ} \mathrm{C}, 240^{\circ} \mathrm{C}, 600^{\circ} \mathrm{C}$ )

In Fig. 9, at $20^{\circ} \mathrm{C}, 200^{\circ} \mathrm{C}, 240^{\circ} \mathrm{C}$ and $600^{\circ} \mathrm{C}$ temperatures, frequency values are similar in all modes. In these conditions can be said that there is no significant effect of temperature. In Fig. 10, at a temperature of $600^{\circ} \mathrm{C}$, frequency values are high in all modes. At the temperature of $20^{\circ} \mathrm{C}$, frequencies have the lowest value in all modes. At temperatures of $200^{\circ} \mathrm{C}$ and $240^{\circ} \mathrm{C}$, frequencies are close to each other in all modes.

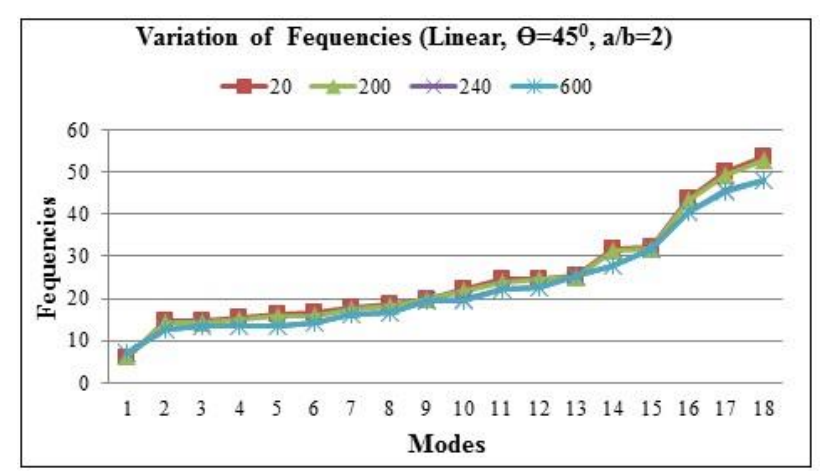

Figure 9. Linear frequency parameters of laminated composite plate model supported by springs at fully clamped boundary conditions $\left(\theta=45^{\circ}\right.$, graphite/epoxy, $\mathrm{a} / \mathrm{b}=2$, temperatures; $20^{\circ} \mathrm{C}, 200^{\circ} \mathrm{C}, 240^{\circ} \mathrm{C}, 600^{\circ} \mathrm{C}$ ) 


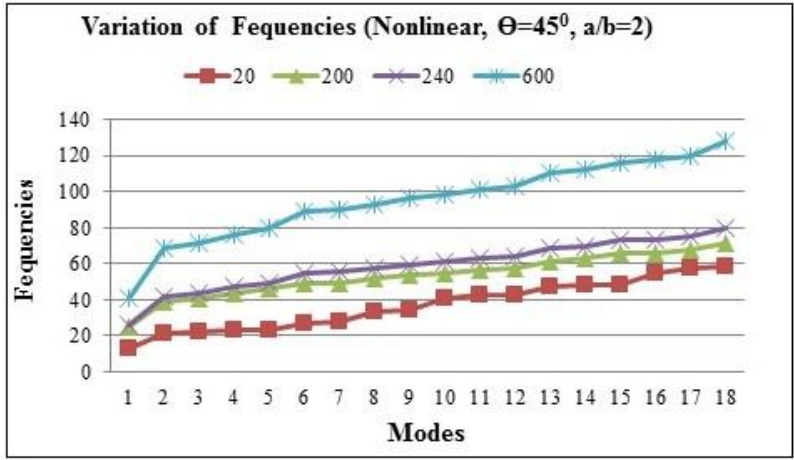

Figure 10. Nonlinear frequency parameters of laminated composite plate model supported by springs at fully clamped boundary conditions $\left(\theta=45^{\circ}\right.$, graphite/epoxy, $\mathrm{a} / \mathrm{b}=2$, temperatures; $20^{\circ} \mathrm{C}, 200^{\circ} \mathrm{C}, 240^{\circ} \mathrm{C}, 600^{\circ} \mathrm{C}$ )

\section{Conclusions}

Nonlinear vibrations analyzes of composite plates on elastic foundations in thermal environments have been presented using classical finite element method. Numerical calculations have been made for symmetric composite plates exposed to high temperatures. The numerical results reveal that foundation stiffness, orientation angle of laminates and temperature rise have significant effects on the natural frequencies of composite plates. Also, dimensions of composite plates have a significant effect on the natural frequencies. Linear and nonlinear vibration analyzes are very important in applications of composite plates. Nonlinear analyzes may help to prevent some negatives situations in the applications of composite plates.

\section{References}

Wang, Z.X. and Shen, H.S.,2011.Nonlinear analysis of sandwich plates with FGM face sheets resting on elastic foundations. Composite Structure,93, 25212532.

Zhen, W., Cheung, Y.K., Lob, S. and Wanji C., 2010. On the thermal expansion effects in the transverse direction of laminated composite plates by means of a global-local higher-order model. International Journal of Mechanical Sciences,52, 970-981.

Wanga, Z.X. and Shen,H.S.,2013. Nonlinear dynamic response of sandwich plates with FGM face sheets resting on elastic foundations in thermal environments. Ocean Engineering ,57, 99-110.
Zenkour, A.M. and Sobhy, M., 2010. Thermal buckling of various types of FGM sandwich plates. Composite Structure,93, 93-102.

Shen, H.S. and Zhu, Z.H., 2012. Postbuckling of sandwich plates with nanotube-reinforced composite face sheets resting on elastic foundations.European Journal of Mechanics - A/Solids, 35, 10-21.

Sofiyev, A.H. and Kuruoglu, N., 2013. Non-linear buckling of an FGM truncated conical shell surrounded by an elastic medium. International Journal of Pressure Vessels and Piping, 107, 38-49.

Li, Z.M. and Lin, Z.Q., 2012. Thermal postbuckling of shear-deformable anisotropic laminated cylindrical shells with temperature-dependent properties. International Journal of Non-Linear Mechanics,47, 984-998.

Xu, Y.M.; Shen, H.S.; Zhang, C.L., 2013. Nonlocal plate model for nonlinear bending of bilayer graphene sheets subjected to transverse loads in thermal environments. Composite Structure,98, 294-302.

Shen, H.S., 2011. Nonlocal plate model for nonlinear analysis of thin films on elastic foundations in thermal environments. Composite Structure,93, 1143-1152.

Zenkour, A.M., Allam, MNM. and Radwan, AF., 2013. Bending of cross-ply laminated plates resting on elastic foundations under thermo-mechanical loading. International Journal of Mechanics and Materials in Design, 9, 239-251.

Zhen, W., Cheung, Y.K., Lob, S. and Wanji, C., 2010. On the thermal expansion effects in the transverse direction of laminated composite plates by means of a global-local higher-order model.International Journal of Mechanical Sciences, 52, 970-981.

Moore, M.; Ziaei-Rad, S. and Salehi, H., 2013. Thermal response and stability characteristics of bistable composite laminates by considering temperature dependent material properties and resin layers. Applied Composite Materials. 20, 87-106.

Petyt, M., 1990. Introduction to Finite Element Vibration Analysis. Cambridge University Press, 125-137. 
Morgül, Ö.K. and Küçükrendeci, İ., 2008. Effects of the mechanical properties of composite laminated plates on the free vibrations. Science and Engineering of Composite Materials, 15, 313-327.

Karadağ, V. and Morgül, Ö.K., 1992. Nonlinear vibrations of rotating turbine blades subjected to transient heat flux and thermal gradient. ASME Engineering System Desing and Analysis, 47 (5), 135-141.

Singha, M.K. and Ramachandra, L.S. and Bandyopadhyay, J.N., 2001. Thermal postbuckling analysis of laminated composite plates. Composite Structure. 54, 453-458.

Han, W. and Petyt, M., 1996. Linear vibration analysis of laminated rectangular plates using the hierarchical finite element method-I. Free vibration. Composite Structure,61 (4), 705-712.

Chow, S.T., Liew, K.M. and Lam, K.Y., 1992. Tranverse Vibration of Symetrically Laminated Rectangular Composite Plates. Composite Structure,20, 213216. 